\title{
Taylor Rule During the Zero or Low Interest Rate Era: The Recent Japanese Case
}

\author{
Yutaka Kurihara \\ Correspondence: Yutaka Kurihara, Department of Economics, Aichi University, 4-60-6 Hiraike, Nakamura, Nagoya, \\ 4538777 Japan.
}

Received: August 25, 2016

Accepted: September 5, 2016

Available online: October 6, 2016

doi:10.11114/aef.v4i1.1909

URL: http://dx.doi.org/10.11114/aef.v4i1.1909

\begin{abstract}
The Taylor rule has been discussed a lot in theoretical and empirical studies. However, interest rates are quite low all over the world. Japan is no exception. Instead of traditional monetary policy based on interest rates, unconventional monetary policy based on money has been ongoing. This paper investigates whether the Taylor rule fits well in the recent Japanese case. With some other variables added to the Taylor rule along with price gap and output gap, the augmented Taylor rule is examined empirically. The empirical results show that the traditional Taylor rule is more appropriate than most augmented ones; however, exchange rate should be taken into account in determining monetary policy. Moreover, a more aggressive monetary policy from the latter part of the 2000s is needed.
\end{abstract}

Keywords: exchange rate, monetary policy, Taylor rule, zero interest rate

\section{Introducation}

\subsection{Monetary Policy Rule}

The Taylor rule assumes that central banks focus on inflation and output when setting monetary policy (see, e.g., Taylor, 1993). The Taylor rule has been used in many cases, both in academic ones and real-world scenarios. Monetary policy has been discussed a lot, and recently, many researchers have noted that monetary policy is conducted systematically. The conduct of monetary policy based on the rules is believed to stabilize economy given the maintenance of transparency and credibility. Some rules, for example, the $\mathrm{k} \%$ rule (money supply), exchange rate control rule, and nominal growth rate policy, have received much attention in the literature; however, the Taylor rule used and discussed a great deal. The reason is that this rule entails both simplicity and realistic appropriations.

This policy rule has been changed and applied to theoretical models in many ways. Also, the policy rule has been examined for the cases of the United States, the Euro area, and developed countries as well as many newly industrialized and developing economies. Few studies have examined the case of Japan and other natiions, where the introduction of the low or zero interest rate policy has been introduced. In some developed economies, there appears to be some need for an augmented Taylor rule.

\subsection{The Japanese Experience Since the 1980s}

Japan enjoyed high economic growth during the 1980s compared with other economies. In particular, stock and land prices increased enormously starting in the middle of the 1980s. After the Plaza Accord with the G5 countries, including Japan, in 1985, the Japanese yen appreciated sharply. Usually appreciation of the yen (i.e., the domestic currency) causes a loss in international competitiveness in Japan; however, exports did not decrease and the economy was not damaged. Consumer prices did not rise greatly, as oil prices did not increase sharply. However, this bubble economy burst at the end of the 1980s, and the Japanese economy experienced recession. In the 1990s, Japan suffered a serious recession with very low and sometimes negative growth rates late in the decade and in the beginning of the 2000s.

The Bank of Japan (BOJ) introduced a new and unprecedented monetary policy, namely, the zero interest rate policy, in February 1999. The BOJ judged that Japan's important economic indicators had come to a pause, so it introduced a policy of maintaining interest rates at an unprecedented low level. Japan's experience with this quantitative easing policy, a more aggressive policy, by the BOJ dates back to March 2001. This approach was unprecedented all over the world. Following a period of zero interest rate policy (February 1999-August 2000), the BOJ adopted this quantitative 
easing policy in March 2001. The main operating target for the BOJ changed from the uncollateralized overnight call rate to be the outstanding balance of the current account at the BOJ. In March 2006, the BOJ exited quantitative easing amid signs that deflation was ending and the recession had disappeared. On July 14, 2006, the zero interest rate policy ended.

After the subprime problems in 2007 and the Lehman shock in 2008, a huge amount of capital flowed into the Japanese financial markets despite that the Japanese economy still was not in a good situation. The Japanese yen appreciated against other currencies, which hit the Japanese economy. In October 2010, the BOJ introduced its comprehensive monetary easing policy to respond to the re-emergence of deflation and a slowing recovery. One key measure was an asset purchase program that involved Japanese government bonds as well as private assets. After that, the Japanese government changed and more aggressive fiscal policy was strongly demanded. The zero interest rate policy by the BOJ was in effect beginning in October 2010 and continue in force now.

In Japan, a drastic new policy, called Abenomics (for Abe, the prime minister), was adopted in 2013. The Japanese government not only conducted drastic fiscal policy but also adopted measures to strengthen competitiveness and economic growth. These policies included possible policy actions to reform the economic structure, such as concentrating resources on innovative research and development, strengthening the foundation for innovation, performing regulatory and institutional reforms, and changing the tax system (increasing the consumption tax and reducing the corporate tax). Moreover, the BOJ cooperated with the Abenomics approach and implemented an unprecedented aggressive monetary policy, in April 2013. It should be noted that Japanese interest rates have been quite low or zero and the unconventional monetary policy instead of interest rates are used to examine the Taylor rule.

Hove (2012) showed that the Taylor rule is different from time to time. Nikoisko-Rzhevskyy and Papell (2013) showed that the Taylor rule does not give a rationale for the age of quantitative easing policy. Rühal (2015) found that the ECB (European Central Bank) policy is less stable than that of the Bundesbank, which violates the Taylor rule. Olson and Wohar (2016) showed that a simple Taylor rule would have substantially improved monetary policy in Germany. Along with these studies, many papers have been published to examine recent cases; however, the results seem to be inconclusive.

The present study takes into account the recent Japanese economic conditions (i.e., low or zero interest rate) and estimates an augmented Taylor rule. Section 2 reviews recent, mainly theoretical, studies. Section 3 reviews empirical studies and provides an augmented Taylor rule that fits well with Japan's recent economic conditions. Section 4 provides the results of the empirical methods and analyzes them. Finally this study ends with a brief summary.

\section{Theoretical Aspects}

As previously noted, the Taylor rule has been augmented in theoretical studies. Clarida, Gali, and Gertler (2000) included lags of the policy interest rate in the equation. Bernanke (2004) showed that asset prices provide forward-looking macroeconomic information that is useful for policymakers. Chortareas and Magonis (2008) indicated that heterogeneity in the estimated coefficients influences the empirical results. Atesoglu (2009) indicated that Keynes's neutral interest rate idea is a good predictor of monetary policy. Badinger (2010) showed that the output gap is negatively related to trade and financial openness of the economy. Annicchiarico and Piergallini (2011) showed that when a country risk premium on debt affects the monetary policy, the Taylor rule does not lead to equilibrium. Castro (2011) indicated that monetary behavior of the ECB and Bank of England are described by a nonlinear rule. Also, Darius (2014) showed that the Taylor rule fits well in nonlinear cases. On the other hand, Alcidi, Flamioni, and Fracasso (2011) found that the linear Taylor rule described the broad contours of monetary policy in the Greenspan era. Mitchell and Pearce (2010) showed that economists believe that real growth rate is less responsive to unemployment rate changes. Sturn and de Haan (2011) indicated that interbank interest rate is included in the Taylor rule and ECB communication is significant. Yagihara (2011) showed that credit channel variables and the net worth capital ratio are statistically significant. Beckman and Wilde (2013) found that real exchange rates adjust and the mean reverts much faster in case of large deviations from equilibrium exchange rates. Kafer (2014) indicated that the Taylor rule should be augmented with exchange rates, asset prices, credit, and spreads. Coibion and Goldstein (2012) found that the Federal Reserve responds disproportionately in low unemployment states. Ibn (2012) founds that the Taylor rule is not a good predictor of interest rate behavior. Mandler (2012) demonstrated that uncertainty about the future condition of the economy and forecast error lead to monetary policy changes. Jaqueson and Marcelo (2013) indicated that a present-value, forward-looking model shows evidence of exchange rate predictability. Modenesi, Martins, and Modenesi (2013) showed that inclusion of a high degree of interest rate smoothing fits well with the Taylor rule. Branch (2014) found that macroeconomic forecast uncertainty is linked with more passive policy. Chow, Lim, and McNeilis (2014) demonstrated that the Taylor rule is preferable when domestic productivity shocks are dominant. Gokcen (2014) indicated that carry trading strategies with Taylor rule perform best in terms of returns and risk. Cogley, Matths, and Sbordone (2015) showed that central banks can reduce inflation; however, adjustment of reaction coefficients on lagged 
inflation and output is more costly. Olson and Wohar (2016) provided the "Taylor curve," for which the efficiency frontier displays a trade-off between the volatility of output and volatility of inflation.

\section{Empirical Aspects}

\subsection{Estimated Equations}

Equation (1) is regressed in this study:

$$
\mathrm{i}_{\mathrm{t}}=\alpha+\beta \pi_{\mathrm{t}}+\gamma \mathrm{y}_{\mathrm{t}}+\varphi \mathrm{X}_{\mathrm{t}}+\varepsilon_{\mathrm{t}}
$$

where $\mathrm{i}_{\mathrm{t}}$ denotes the money market rate (overnight rate). $\pi_{\mathrm{t}}=\left(\mathrm{p}-\mathrm{p}^{*}\right), \mathrm{p}$ is consumer price rate and $\mathrm{p}^{*}=2$, which was set by the BOJ as a target rate starting in 2014. $y_{t}$ denotes the output gap. $t$ denotes time. Finally, $X_{t}$ denotes a vector of other variables considered to affect monetary policy.

The traditional Taylor rule is shown as equation (2).

$$
\mathrm{i}_{\mathrm{t}}=\alpha+\beta \pi_{\mathrm{t}}+\gamma \mathrm{y}_{\mathrm{t}}+\varepsilon_{\mathrm{t}}
$$

As argued by Taylor (1993) and Roskelley (2016), central banks should not blindly follow a simple rule. Although exclusion of necessary variables in setting monetary policy may result in large deviations from estimated policy rule, an augmented Taylor rule, as shown in equation (1), is employed in this study. Concretely, along with price gap and output gap that are used in the Taylor rule, stock prices, exchange rates, and dispersions of price and output, are employed in this study.

Many studies have examined the inflation gap. Gorter, Jacobs, and de Haan (2008) found that the coefficient of realized inflation is not significantly different from zero in the Euro area. Mitchell and Pearce (2010) indicated that the Federal Reserve sets short-term interest rates with less weight on the inflation gap than the Taylor rule. Rajendra (2013) showed that policy rate of Nepal has reacted positively and significantly to the inflation gap. Ikeda (2014) found that when monetary policy omits asymmetry and volatility, a more aggressive response to inflation than the Taylor rule is required.

Also, for the output gap, Nikoisko-Rzhevskyy and Papell (2012) showed that the Federal Reserve responded strongly to the negative output gap. Ebru, Kivicim, and Ozan (2013) indicated that a structurally extended Kalman filter should be used for the output gap. Rajendra (2013) showed that the policy rate of Nepal has not reacted to the output gap.

For X (stock prices, exchange rates, and dispersions of price and output), there are some candidates. Four variables are selected for examination.

The first is exchange rates. Bask and Selander (2009) suggested that exchange rates should be included in the Taylor rule when there is heterogeneity in the currency trade. Wang and $\mathrm{Wu}$ indicated that the Taylor rule fits better than the purchasing power parity model (PPP) and the forward premium model in exchange rate determination. Wilde (2012) indicated that Taylor rule deviations are important determinants of exchange rates. Alba, Park, and Xie (2015) showed some evidence of out-of-sample exchange rate predictability for Brazil, Czech Republic, Hungary, Philippines, Thailand, and South Africa. Japanese exchange rates fluctuate largely, so this factor cannot be ignored.

Stock prices are included in this equation. Rigbon and Sack (2003) and Fuhrer and Tootell (2008) found that equity prices impact policy interest rates. Morley and Wei (2012) demonstrated that house price relates negatively to interest rate. Erler, Drescher, and Križanac (2013) indicated that the Federal Reserve responds implicitly to asset price booms in the real estate market. Lei (2014) showed that the output gap and inflation lower stock liquidity and increase commonality in liquidity.

Just before the first initial data are released and again when confirmation data are released, economists and private economic institutions expect each report, and when they are published, market participants (sometimes computers) see them and conduct transactions, invest, and sometimes speculate using the published data. Sometimes a large variety of expectations and the transactions that are based on such expectations destabilize or stabilize markets. Molodtsova, Nikolsko-Rzhevskyy, and Papell (2011) showed that predictability is found with both one quarter ahead and longer horizon forecasts. Lee, Olekalns, and Shields (2013) indicated that with the use of data that are available in real time, the Taylor rule useful in the United Kingdom and Australia. Both of the dispersions of output and inflation are examined in this study.

\subsection{Data and Empirical Methods}

To estimate the Taylor rule, quarterly data with a weighted GDP deflator are used. The real, effective exchange rate is used for exchange rate. The output deflator is from BOJ, first initial data are from the Japanese Statistical Bureau, and other variables are from International Financial Statistics (IMF). All of the data are quarterly and the sample period is from 2000Q1 to the most recent, 2016Q1. 
Empirical methods are ordinary least squares (OLS) and robust estimation. Robust estimation is unlike maximum likelihood estimation. OLS estimates for regression are sensitive to the observations that do not follow the pattern of the other observations. This is not a problem if the outlier is simply an extreme observation from the tail of a normal distribution; however, if the outlier is from non-normal measurement error or some other violation of standard OLS, it compromises the validity of the regression results if a nonrobust regression method is employed. In this study, the sample size is small, so along with the usual OLS, robust estimation is used for estimations.

\section{Empirical Results}

\subsection{Appropriateness of the Taylor Rule}

Empirical results are shown in Table 1 (OLS) and Table 2 (robust least squared).

Table 1. Taylor rule and augmented Taylor rule estimation results: OLS.

\begin{tabular}{|c|c|c|c|c|c|c|}
\hline $\begin{array}{l}\text { Equation } \\
\text { number }\end{array}$ & (1) & (2) & (3) & (4) & (5) & (6) \\
\hline $\mathrm{C}$ & $\begin{array}{c}0.105 * * * \\
(3.127)\end{array}$ & $\begin{array}{c}0.110 * * * \\
(3.297)\end{array}$ & $\begin{array}{c}0.114 * * * \\
(3.395)\end{array}$ & $\begin{array}{c}0.114 * * * \\
(3.334)\end{array}$ & $\begin{array}{c}0.141 * * * \\
(5.329)\end{array}$ & $\begin{array}{c}-0.124 * * * \\
(-3.297)\end{array}$ \\
\hline Price gap & $\begin{array}{l}-0.027 * \\
(-1.741)\end{array}$ & $\begin{array}{l}-0.029 * \\
(-1.845)\end{array}$ & $\begin{array}{l}-0.025^{*} \\
(-1.719)\end{array}$ & $\begin{array}{l}-0.026^{*} \\
(-1.643)\end{array}$ & & $\begin{array}{c}-0.009 \\
(-0.832)\end{array}$ \\
\hline Output gap & $\begin{array}{c}0.031 * * * \\
(3.146)\end{array}$ & $\begin{array}{c}0.036 * * * \\
(3.466)\end{array}$ & $\begin{array}{c}0.035 * * * \\
(3.477)\end{array}$ & $\begin{array}{c}0.036^{* * * *} \\
(3.427)\end{array}$ & & $\begin{array}{c}0.029 * * * \\
(4.166)\end{array}$ \\
\hline Stock price & & $\begin{array}{c}-0.003 \\
(-1.384)\end{array}$ & & $\begin{array}{c}-0.001 \\
(-0.374)\end{array}$ & & $\begin{array}{c}-0.001 \\
(-0.654)\end{array}$ \\
\hline $\begin{array}{l}\text { Exchange } \\
\text { rate }\end{array}$ & & & $\begin{array}{c}-0.007 \\
(-1.495)\end{array}$ & $\begin{array}{c}-0.005 \\
(-0.661)\end{array}$ & & $\begin{array}{c}0.002 \\
(0.452)\end{array}$ \\
\hline $\begin{array}{l}\text { Price } \\
\text { dispersion }\end{array}$ & & & & & $\begin{array}{c}0.024 \\
(0.395)\end{array}$ & $\begin{array}{c}0.065^{*} \\
(1.816)\end{array}$ \\
\hline $\begin{array}{l}\text { Output } \\
\text { dispersion }\end{array}$ & & & & & $\begin{array}{c}0.052 * * \\
(2.559)\end{array}$ & $\begin{array}{c}0.020 \\
(1.547)\end{array}$ \\
\hline Adj.R2 & 0.183 & 0.202 & 0.208 & 0.189 & 0.102 & 0.753 \\
\hline F-statistic & $\begin{array}{c}5.480 \\
(0.008)\end{array}$ & $\begin{array}{c}4.380 \\
(0.009)\end{array}$ & $\begin{array}{c}4.518 \\
(0.008)\end{array}$ & $\begin{array}{c}3.344 \\
(0.019)\end{array}$ & $\begin{array}{c}3.283 \\
(0.048)\end{array}$ & $\begin{array}{l}18.491 \\
(0.000)\end{array}$ \\
\hline
\end{tabular}

Note. Figures in parentheses are t-statistics and probability for F-statistics. ***, **, and * denote 1\%, 5\%, and $10 \%$ significance levels respectively.

Table 2. The Taylor rule and augmented Taylor rule estimation results: Robust least squares.

\begin{tabular}{|c|c|c|c|c|c|c|}
\hline $\begin{array}{l}\text { Equation } \\
\text { number }\end{array}$ & (7) & (8) & (9) & (10) & (11) & (12) \\
\hline $\mathrm{C}$ & $\begin{array}{c}0.011 \\
(1.565)\end{array}$ & $\begin{array}{l}0.016^{* *} \\
(2.182)\end{array}$ & $\begin{array}{l}0.019 * * * \\
(2.772)\end{array}$ & $\begin{array}{c}0.018 * * * \\
(2.636)\end{array}$ & $\begin{array}{c}0.038 * * * \\
(4.535)\end{array}$ & $\begin{array}{c}-0.117 * * * \\
(-3.967)\end{array}$ \\
\hline Price gap & $\begin{array}{l}-0.005^{*} \\
(-1.641)\end{array}$ & $\begin{array}{l}-0.005^{*} \\
(-1.643)\end{array}$ & $\begin{array}{c}-0.004 \\
(-1.335)\end{array}$ & $\begin{array}{c}-0.004 \\
(-1.201)\end{array}$ & & $\begin{array}{c}-0.005 \\
(-0.946)\end{array}$ \\
\hline Output gap & $\begin{array}{c}-0.013 * * * \\
(-6.152)\end{array}$ & $\begin{array}{c}-0.011 * * * \\
(-4.559)\end{array}$ & $\begin{array}{c}-0.011 * * * \\
(-5.202)\end{array}$ & $\begin{array}{c}-0.011 * * * \\
(-5.175)\end{array}$ & & $\begin{array}{c}0.033 * * * \\
(5.999)\end{array}$ \\
\hline Stock price & & $\begin{array}{l}-0.001 * * \\
(-1.999)\end{array}$ & & $\begin{array}{l}0.0002 \\
(0.366)\end{array}$ & & $\begin{array}{c}-0.001 \\
(-0.960)\end{array}$ \\
\hline Exchange rate & & & $\begin{array}{c}-0.003 * * * \\
(-3.123)\end{array}$ & $\begin{array}{l}-0.003 * * \\
(-2.207)\end{array}$ & & $\begin{array}{l}-0.0002 \\
(-0.079)\end{array}$ \\
\hline Price dispersion & & & & & $\begin{array}{c}-0.019 \\
(-1.019)\end{array}$ & $\begin{array}{c}0.026 \\
(0.343)\end{array}$ \\
\hline $\begin{array}{l}\text { Output } \\
\text { dispersion }\end{array}$ & & & & & $\begin{array}{l}-0.010 * \\
(-1.677)\end{array}$ & $\begin{array}{c}0.029 * * * \\
(2.874)\end{array}$ \\
\hline Adj.Rw-squared & 0.598 & 0.612 & 0.688 & 0.698 & 0.097 & 0.913 \\
\hline $\begin{array}{l}\text { Rn-squared } \\
\text { statistic }\end{array}$ & $\begin{array}{l}47.314 \\
(0.000)\end{array}$ & $\begin{array}{l}43.863 \\
(0.000)\end{array}$ & $\begin{array}{l}58.869 \\
(0.000)\end{array}$ & $\begin{array}{l}58.003 \\
(0.000)\end{array}$ & $\begin{array}{c}3.305 \\
(0.191)\end{array}$ & $\begin{array}{c}279.806 \\
(0.000)\end{array}$ \\
\hline
\end{tabular}


Note. Figures in parentheses are z-statistics for robust estimation and probability for Rn-squared statistic. ***, **, and * denote $1 \%, 5 \%$, and $10 \%$ significance levels respectively.

Not all of the results are not conclusive; however, most of them are conclusive and interesting. It should be noted that the results show that the traditional Taylor rule is appropriate. Also, exchange rate should be taken into account in determining monetary policy. This is a different point from the traditional Taylor rule. However, stock prices and data dispersions have not influenced policy interest rates. The reasons may be complex; however, interest rates and growth rates have been quite low, so they have not had a strong influence on interest rates.

\subsection{Evaluation of Monetary Policy since the $2000 \mathrm{~s}$}

Finally, an ideal policy interest rate is calculated using the coefficients of equations (1) and (6), and the realistic one minus this ideal one is calculated. The results are shown in Figure 1 [equations (1) and (6)].

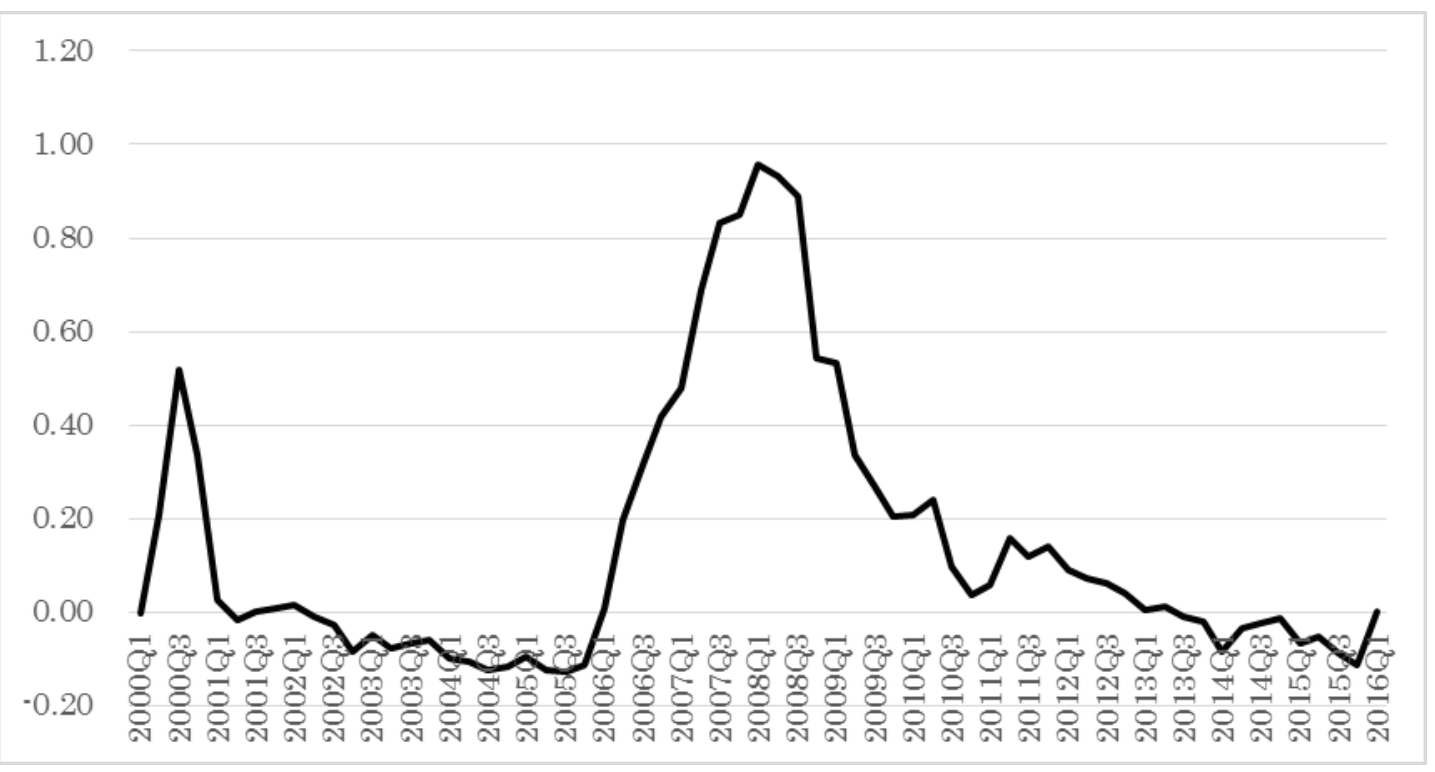

Figure 1. Difference between realistic and calculated interest rates [equation (1)]

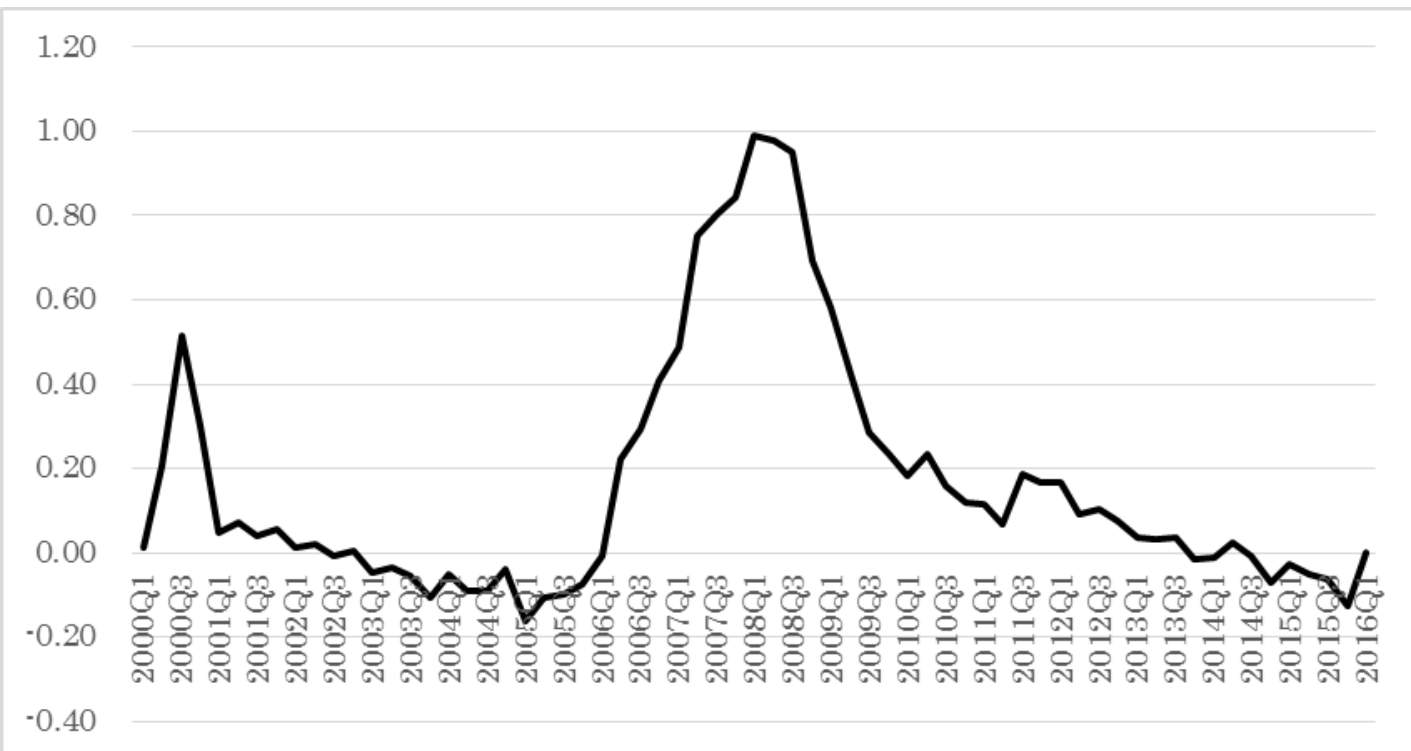

Figure 2. Difference between realistic and calculated interest rates [equation (6)].

The results are clear. More aggressive monetary policy is needed starting in the latter part of the 2000s; unconventional and aggressive policies had been in place.

\section{Conclusions}

This paper investigated whether the Taylor rule fits well the case of Japan in the 2000s. The Taylor rule assumes that central banks focus on inflation and output when setting monetary policy. With the addition of some other variables to the original Taylor rule, this study empirically examined the augmented Taylor rule. Four variables are selected for 
examination.The results show that the traditional Taylor rule was appropriate in most cases; however, exchange rate should be taken into account in setting monetary policy. Moreover, a more aggressive monetary policy is needed for the latter part of the 2000s.

Although most results in this study are conclusive, there is some room for further study. As noted, the results are not conclusive for different countries, time, variables, empirical methods, and so on. The empirical results are not necessarily conclusive. Of course, simplicity and transparency outperform the critical opinion, but many more cases should be examined. Also, because the ECB and BOJ introduced the negative interest rate policy, interest rates are quite low or almost zero in many industrialized countries. In most newly industrialized and developing economies, prices have not risen as must as in the past, and different analytic methods are needed for this. Further study is needed for the field of monetary policy rule.

\section{Acknowledgements}

I appreciate anoumous referees for their valuable comments and suggestions. I was supported by JSPS KAKENHI Grant Number $15 \mathrm{H} 03366$ for this work.

\section{References}

Alba, J. D., Park, D., \& Xie, T. (2015). Predictability of exchange rates with Taylor rule fundamentals: Evidence from inflation-targeting emerging countries. Emerging Markets Finance and Trade, 51, 714-728. http://dx.doi.org/10.1080/1540496X.2015.1046344

Alcidi, C., Flamini, A., \& Fracasso, A. (2011). Policy regime changes, judgment and Taylor rules in the Greenspan era. Economica, 78, 89-107. http://dx.doi.org/10.1111/1468-0335.2009.00777.x

Annicchiarico, B., \& Piergallini, A. (2011). Country-specific risk premium, Taylor rules, and exchange rates. Economic Notes by Banca Monte dei Paschi di Siena SpA, 40(1/2), 1-27.

Atesoglu, H. S. (2009). Taylor and Keynesian monetary policy rules. Journal of Post Keynesian Economics, 31(3), 485-500. http://dx.doi.org/10.2753/PKE0160-3477310306

Badinger, H. (2010). Globalization, Taylor rules and inflation. Applied Economics Letters, 17, 263-267. http://dx.doi.org/10.1080/13504850701720114

Bask, M., \& Selander, C. (2009). Robust Taylor rules under heterogeneity in currency trade. International Economic Policy, 6, 283-313. http://dx.doi.org/10.1007/s10368-009-0131-6

Beckman, J., \& Wilde, W. (2013). Taylor rule equilibrium exchange rates and nonlinear mean reversion. Applied Financial Economics, 23(13), 1097-1107. http://dx.doi.org/10.1080/09603107.2013.788780

Bernanke, B. S. (2004). What policymakers can learn from asset prices. Paper presented at the Investment Analysis Society of Chicago.

Branch, W. A. (2014). Newcasting and the Taylor rule. Journal of Money, Credit and Banking, 46(5), 1035. http://dx.doi.org/1055. 10.1111/jmcb.12128

Castro, V. (2011). Can central bank's monetary policy be described by a linear (augmented) Taylor rule or by a nonlinear rule? Journal of Financial Stability, 7(4), 228-246. http://dx.doi.org/10.1016/j.jfs.2010.06.002

Chortareas, G., \& Magonis, G. (2008). What do we learn from Taylor rule estimations? A meta-analysis. Ekonomia, $11(2), 112-120$.

Chow, H. K., Lim, G. C., \& McNeilis, P. D. (2014). Monetary regime choice in Singapore: Would a Taylor rule outperform exchange-rate management? Journal of Asian Economics, 30, 63-81. http://dx.doi.org/10.1016/j.asieco.2013.09.001

Clarida, R., Gali, J., \& Gertler, M. (2000). Monetary policy rules and macroeconomic stability: Evidence and some theory. Quarterly Journal of Economics, 115, 147-180. http://dx.doi.org/10.1016/10.1162/003355300554692

Cogley, T., Matths, C., \& Sbordone, A. M. (2015). Optimized Taylor rules for disinflation when agents are learning. Journal of Monetary Economics, 72, 131-147. http://dx.doi.org/10.1016/j.moneeco.2015.02.003

Coibion, O., \& Goldstein, D. (2012). One for some, one for all? Taylor rules and interregional heterogeneity, Journal of Money, Credit and Banking, 44(2/3), 13-31. http://dx.doi.org/10.1111/j.1538-4616.2011.00493.x

Darius, K. (2014). Nonlinear Taylor rule for the European Central Bank. Economics Bulletin, 34(3), 1798-1804.

Ebru, Y., Kivicim, M., \& Ozan, H. (2013). A survey on time-varying parameter Taylor rule: A model modified with interest rate pass-through. Economic Systems, 37(1), 122-134. http://dx.doi.org/10.1016/j.ecosys.2012.08.002 
Erler, A., Drescher, C., \& Križanac, D. (2013). The Fed's TRAP: A Taylor-type rule with asset prices. Journal of Economics and Finance, 37, 136-149. http://dx.doi.org/10.1007/s12197-01109173-z

Fuhrer, J., \& Tootell, G. (2008). Eyes on the prices: How did the fed respond to the stock market. Journal of Monetary Economics, 55(4), 796-805. http://dx.doi.org/10.1016/j.jmoneco.2008.03.005

Gokcen, O. (2014). Is implied Taylor rule interest rate applicable as a carry trade strategy? International Journal of Economics and Financial Issues, 4(4), 909-919.

Gorter, J., Jacobs, J., \& de Haan, J. (2008). Taylor rules for the ECB using Expectations data. Journal of Economics, 110(3), 473-488. http://dx.doi.org/10.1111/j.1467-9442.2008.00547.x

Hove, R. S. (2011). Rules versus dictation: A Taylor rule for Denmark. Nationalokonomisk Tidsskrift, 150(1), 21-41.

Ibn, B. M. (2012). Taylor rule and monetary policy in Ghana. International Journal of Economics and Finance, 4(7), 15-21. http://dx.doi.org/10.5539/ijef.v4n7p15

Ikeda, T. (2014). Asymmetric preferences in real-time learning and the Taylor rule. Economics Letters, 124(3), 487-489. http://dx.doi.org/10.1016/j.econlet.2014.07.017

Jaqueson, G. K., \& Marcelo, M. L. (2013). Taylor rules and exchange rate predictability in emerging economies, Journal of International Money and Finance, 32(1), 1008-1031. http://dx.doi.org/10.1016/j.jimonfin.2012.08.006

Kafer, B. (2014). The Taylor rule and financial stability: A literature review with application for the Eurozone. Review of Economics, 65(2), 159-192.

Lee, K., Olekalns, N., \& Shields, K. (2013). Meta Taylor rules for the UK and Australia: Accommodating regime uncertainty in monetary policy analysis using model averaging methods. The Manchester School, 81(s3), 28-53. http://dx.doi.org/10.1111/manc. 12000

Lei, J. (2015). Stock liquidity and the Taylor rule. Journal of Empirical Finance, 28, 202-214. http://dx.doi.org/10.1016/j.empfin.2014.07.001

Mandler, M. (2012). Decomposing federal funds rate forecast uncertainty using time-varying Taylor rules and real-time data. North American Journal of Economics and Finance, 23(2), 228-245. http://dx.doi.org/10.1016/j.najef.2012.01.003

Mitchel, K., \& Pearce, D. (2010). Do Wall Street economists believe in Okun's law and the Taylor Rule? Journal of Economics and Finance, 34, 196-217. http://dx.doi.org/10.1007/s12197-009-9085-3

Modenesi, A., Martins, N. M., \& Modenesi, R. (2013). A modified Taylor rule for the Brazilian economy: Convention and conservatism in eleven years of inflation targeting (2000-2010). Journal of Post Keynesian Economics, 35(3), 463-480. http://dx.doi.org/10.2753/PKE0160-3477350308

Molodtsova, T., Nikolsko-Rzhevskyy, A., \& Papell, D. H. (2011). Taylor rules and the euro. Journal of Money, Credit and Banking, 43(2/3), 535-552. http://dx.doi.org/10.1111/j.1538-4616.2011.00384.x

Morley, B., \& Wei, Q. (2012). The Taylor rule and house price uncertainty. Applied Economics Letters, 19, 1449-1453. http://dx.doi.org/10.1080/13504851.2011.633882

Nikoisko-Rzhevskyy, A., \& Papell, D. H. (2012). Taylor rule and the Great inflation. Journal of Macroeconomics, 34(4), 903-918. http://dx.doi.org/10.1016/j.jmacro.2012.05.007

Nikoisko-Rzhevskyy, A., \& Papell, D. H. (2013). Taylor's rule versus Taylor rules. International Finance, 16(1), 71-93. http://dx.doi.org/10.1111/j.1468-2362.2013.12024.x

Olson, E., \& Wohar, M. E. (2016). An evaluation of ECB policy in the Euro's big four. Journal of Macroeconomics, 48, 203-213. http://dx.doi.org/10.1016/j.jmacro.2016.07.006

Rajendra, A. (2013). Applicability of Taylor's rule in a Nepalese monetary policy. Economic Affairs, 58(3), 195-205. http://dx.doi.org/10.5958/j.0976-4666.58.3.003

Rigbon, R., \& Sack, B. (2003). Measuring the reaction of monetary policy to the stock market. Quarterly Journal of Economics, 118(2), 639-669.

Roskelley, K. D. (2016). Augmenting the Taylor rule: Monetary policy and the bond market. Economics Letters, 144, 64-67. http://dx.doi.org/10.1016/j.econlet.2016.05.002

Rühal, T. (2015). Taylor rules revisited: ECB and Bundesbank in comparison. Empirical Economics, 48, 951-967. http://dx.doi.org/10.1007/s.00181-014-0820-z 
Sturn, J.-E., \& de Haan, J. (2011). Does central bank communication really lead to better forecasts of policy decision? New evidence based on a Taylor rule model for the ECB. Review of World Economics, 147, 41-58. http://dx.doi.org/10.1007/s10290-010-0076-4

Taylor, J. B. (1993). Discretion versus policy rules in practice. Public Policy, 39, 195-214.

Wang, J., \& Wu, J. (2012). The Taylor rule and forecast intervals for exchange rates. Journal of Money, Credit and Banking, 44(1), 103-144. http://dx.doi.org/10.1111/j.1538-4616.2011.00470.x

Wilde, W. (2012). The influence of Taylor rule deviations on the real exchange rate. International Review of Economics and Finance, 24(1), 51-61. http://dx.doi.org/10.1016/j.iref.2012.01.001

Yagihara, T. (2011). Estimating Taylor rules in a credit channel environment. North American Journal of Economics and Finance, 22(3), 344-364. http://dx.doi.org/10.1016/j.najef.2011.07.001

\section{Copyrights}

Copyright for this article is retained by the author(s), with first publication rights granted to the journal.

This is an open-access article distributed under the terms and conditions of the Creative Commons Attribution license which permits unrestricted use, distribution, and reproduction in any medium, provided the original work is properly cited. 